Article

\title{
Sustainable Development and Rural Tourism in Depopulated Areas
}

\author{
José María López-Sanz ${ }^{1}\left[\right.$, Azucena Penelas-Leguía ${ }^{1}\left[\right.$, Pablo Gutiérrez-Rodríguez ${ }^{2}$ (D) \\ and Pedro Cuesta-Valiño ${ }^{1, *(\mathbb{D})}$ \\ 1 Department of Economics and Business Management, Universidad de Alcalá, 28802 Alcalá de Henares, Spain; \\ jm.lopez@uah.es (J.M.L.-S.); azucena.penelas@uah.es (A.P.-L.) \\ 2 Department of Business Administration, University of León, 24071 León, Spain; pablo.gutierrez@unileon.es \\ * Correspondence: pedro.cuesta@uah.es
}

Citation: López-Sanz, J.M.;

Penelas-Leguía, A.;

Gutiérrez-Rodríguez, P.;

Cuesta-Valiño, P. Sustainable

Development and Rural Tourism in

Depopulated Areas. Land 2021, 10 ,

985. https://doi.org/10.3390/

land10090985

Academic Editor: Yurui Li

Received: 19 August 2021

Accepted: 15 September 2021

Published: 17 September 2021

Publisher's Note: MDPI stays neutral with regard to jurisdictional claims in published maps and institutional affiliations.

Copyright: (c) 2021 by the authors. Licensee MDPI, Basel, Switzerland. This article is an open access article distributed under the terms and conditions of the Creative Commons Attribution (CC BY) license (https:/ / creativecommons.org/licenses/by/ $4.0 /)$.

\begin{abstract}
The high degree of depopulation in certain areas of Spain is a serious threat to the country, and is aggravated by the ongoing loss of population from those areas. Rural tourism is one of the activities that can help prevent this depopulation. However, to successfully promote such tourism, we must consider the elements that have the greatest influence on tourists when they choose one location over another, or one accommodation over another. Extensive data have been collected from 1658 valid surveys of tourists in one of the most depopulated areas of Spain. Several multivariate techniques were then applied to the data, including Principal Component Analysis (PCA) and Multiple Classification Analysis (MCA). Factors were obtained that identified both the different motivations that influence tourists, and the variables that identify the province based on its image. An analysis was then made of how both the variables thus identified the influence of the formation of the image that tourists take away from the visit. Tourists are most strongly motivated by natural landscapes, monuments, or events of cultural interest, i.e., natural and cultural attractions rather than social ones, and the cognitive image has the greatest influence on the formation of the new image. The principal findings of this research are that the future of many of these depopulated areas depends on successfully promoting both their beautiful landscapes and their cultural heritage, as well as developing and improving the areas themselves so that the depopulation is slowed down or even reversed, to the benefit of the local population. This would also benefit the local and regional authorities and the establishments linked to rural tourism in the area, increasing their profits and raising the level of employment in the province.
\end{abstract}

Keywords: sustainable development; rural tourism; depopulation; destination image; motivations

\section{Introduction}

In Spain, tourism has traditionally been one of the activities that underpins the economy. Its contribution to the GNP has been increasing, and in recent years, has accounted for about $15 \%$. This shows the importance of tourism to the nation. The global economic crisis has affected all sectors, including tourism, although this sector's characteristics have enabled it to better resist this adverse environment and respond faster to the crisis [1] Despite its immense potential, growth has not been the same in all areas. Along with the extensively developed tourism on the Spanish coast, tourism should be developed and promoted in the less populated areas of the interior and become a source of wealth for these areas. This is where rural tourism comes into the equation. This type of tourism has undergone considerable development in recent decades, becoming an alternative to Spain's traditional tourism. Visitors are looking for experiences other than the usual sun and sand. They need new sensations, and seek out a more individualized and flexible tourism. They are also considering new forms of accommodation, and show a growing interest in contact with nature [2]. All of these factors help us to understand the boom in rural tourism. More 
and more, people prefer to participate in a more active and environmentally responsible tourism involving new and different activities.

Rural areas play a leading role in this new lifestyle, as the landscapes of the interior, including some of the country's most depopulated areas, have become attractive tourist destinations. These areas are developing new ways of enjoying a tourist experience that is rural and green, and based on history and nature. They are also the right place to develop adventure activities, active tourism, and other types of activities [3]. As a result, it has been possible to "de-seasonalize" this tourism [4], since it is not subject to weather conditions, unlike the more traditional sun and sand tourism. Similarly, a creative tourism destination is also less seasonally dependent. In addition, it offers greater profitability, as this type of tourist has greater purchasing power [5].

For many rural depressed areas with demographic problems, rural tourism is an additional activity, which has made agriculture - the traditional function of these placessecondary, and has turned them into multi-functional spaces [6]. Policies focused on rural areas at the local, regional, and state level have therefore evolved to meet the new needs of society. During the 1990s and the first decade of the 2000s, the European Union and Spain's central government launched various development programs in rural areas. These were the LEADER initiative (in French; Liaison entre actions de dévelopement de l'économie rurale; In English; Links between actions for the development of the rural economy), consisting of three phases (LEADER I, LEADER II, and LEADER+); and the PRODER programs, having two phases (PRODER and PRODER 2). The ultimate objective was the implementation of a set of economic initiatives capable of constituting a solid base for the launching or re-launching of economic activity, with the necessary tools for gradual progress and future consolidation [7]. These, however, should not be considered the absolute panacea to alleviate the numerous existing problems [8]. Authors such as Ascanio [9] believe that tourism in rural areas should not displace their own economic and cultural activities in those spaces; on the contrary, it should stimulate and support them. In this sense, tourism must assume an important role in the rural environment, with three specific aims-economic development, conservation and rehabilitation of the socio-cultural and historical-artistic heritage, and revitalization of local life-by favoring contact between rural societies and a tourist population of urban origin [7]. It is also appropriate to point out that the choice of tourist destination is closely linked to linguistic proximity, from both a statistical and economic point of view. Inland rural tourism should try to take advantage of linguistic proximity to assist its development [10].

Developing rural tourism activities can therefore help alleviate some of the problems that have arisen in these areas, such as high unemployment rates, rural exodus, and dependence on the primary sector [11]. To this end, it should be recognized that local traditions, residents' habits, lifestyles, and local gastronomy have been identified as the main factors in the diversification of destinations, as they are capable of impressing the traveler and influencing their preferences [12]. Collaboration between local people and tourists should be the frame of reference for promoting so-called smart tourist destinations [13]. These destinations, however, must be conceived of not as the sum of individual smart destination groupings, but as smart tourist regions, since this offers synergies that would be unattainable if this development were carried out individually [14]. Rural areas can develop productive activities, both agricultural-based and tourism-based, provided that they are sustainable both in terms of the environment and the local community [15].

Moreover, this problem of depopulation is not unique to Spain. In different regions of southern Europe, depopulation reached its maximum in the second half of the 20th century and still continues today [16]. Since 1989, most of these countries have experienced a population decline and accelerated aging. Low levels of fertility and mass emigration of young people are primarily responsible for these adverse trends $[17,18]$. Rural depopulation may be understood as a process affecting regions where the rural exodus outstripped natural growth, thereby reducing the total number of inhabitants to a critical level, particularly in terms of population density and aging of demographic structures [19]. There are numerous 
papers and reports that have analyzed the phenomenon of rural-urban migration and rural depopulation in Europe [16,20,21]. The rural exodus has taken place in Europe since the early decades of the second half of the twentieth century, when many people, especially younger people, have migrated to the cities looking for job opportunities, an improved quality of life, and higher wages than in the countryside [22]. In some Western European countries, this took place mainly in the last third of the 19th century and the first half of the 20th century, for example in France and the United Kingdom [23-26]. Europe's rural areas are experiencing structural changes, particularly in industries based on natural resources and supporting these economies, affecting, in particular, the southern countries. These changes have contributed to a decrease in production, and consequently, to the reduction of jobs in rural communities, and to the emigration of its residents seeking new opportunities elsewhere, especially in larger urban areas [27]. The depopulation of European rural areas is a huge challenge, and constitutes one of the most current issues of numerous disciplines [28]

Our study focused on the province of Soria, the most depopulated in Spain. Its population, according to the 2020 census [29], of 88,884 inhabitants, is practically half that of 1910 (156,354 registered inhabitants [29]). However, it is a province with a very diverse landscape-highlighting the Laguna Negra Natural Park, the Lobos River Canyon, and the La Fuentona Natural Monument-as well as countless historical and archaeological sites, such as the Archaeological Site of Numancia, Calatañazor, the Archaeological Site of Uxama, El Burgo de Osma Cathedral, or the Hermitage of San Baudelio.

As you can see in Figure 1, this province is located just 300 kilometers northwest of Spain's capital, Madrid. The enormous demographic "desertification" that the province has suffered, together with the disappearance of many municipalities and the loss of cultural heritage, has led to a redistribution of the province's population [30]. The population has become concentrated in those towns and cities that were already larger, with the city of Soria—the provincial capital—benefitting the most.

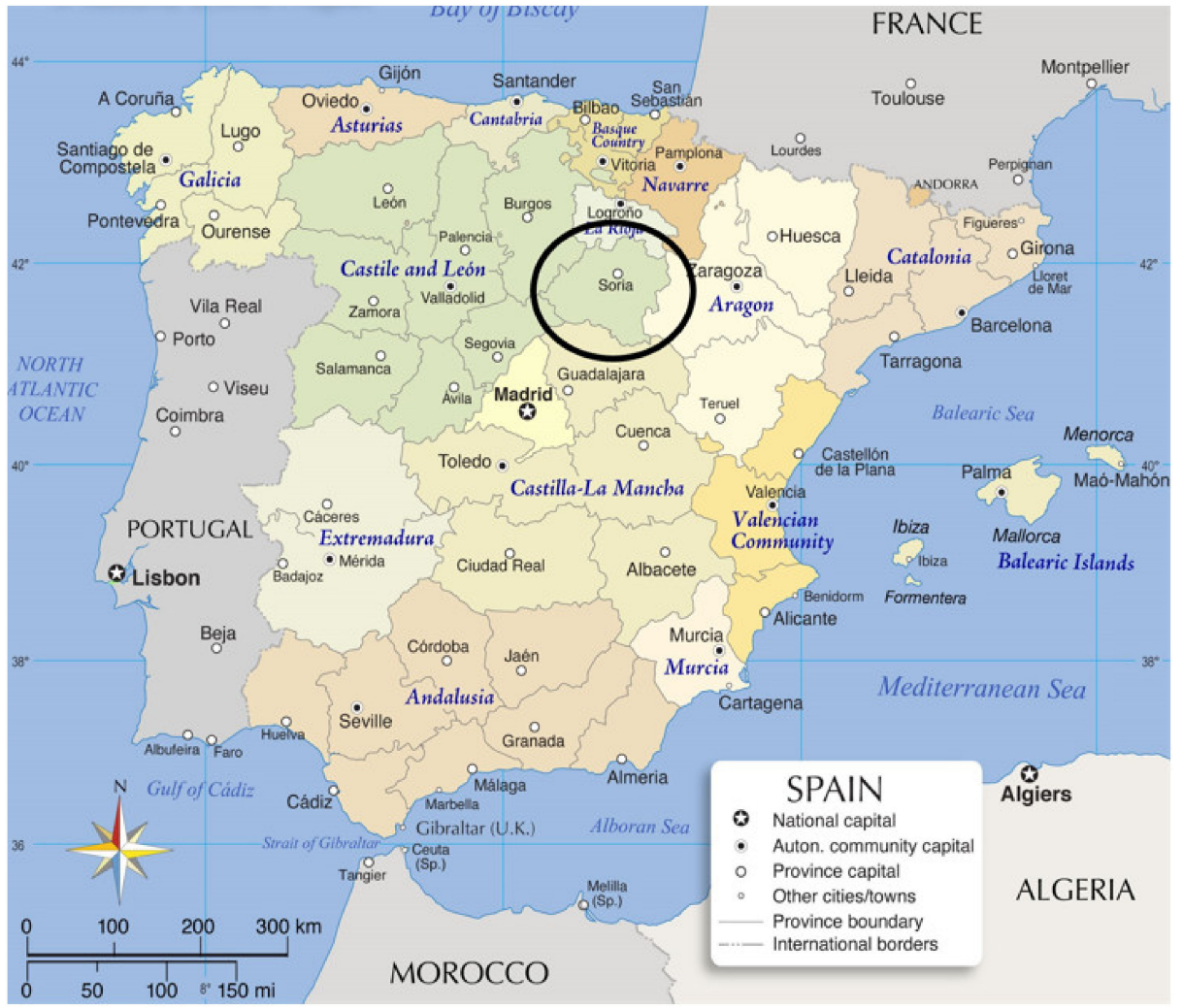

Figure 1. Map of Spain with the location of the province of Soria. 
The development of rural tourism in this province could be the key to preventing further depopulation. Moreover, the data justifies this opinion.

Figure 2 shows that the trend in recent years in the numbers of travelers and overnight stays is upward, with both those statistics having tripled over the last fifteen years. This growth has occurred despite the significant decline during the years of the global economic crisis, with numbers having recovered since 2014. There was also a significant drop in both travelers and overnight stays during 2020, due to the global COVID-19 pandemic.

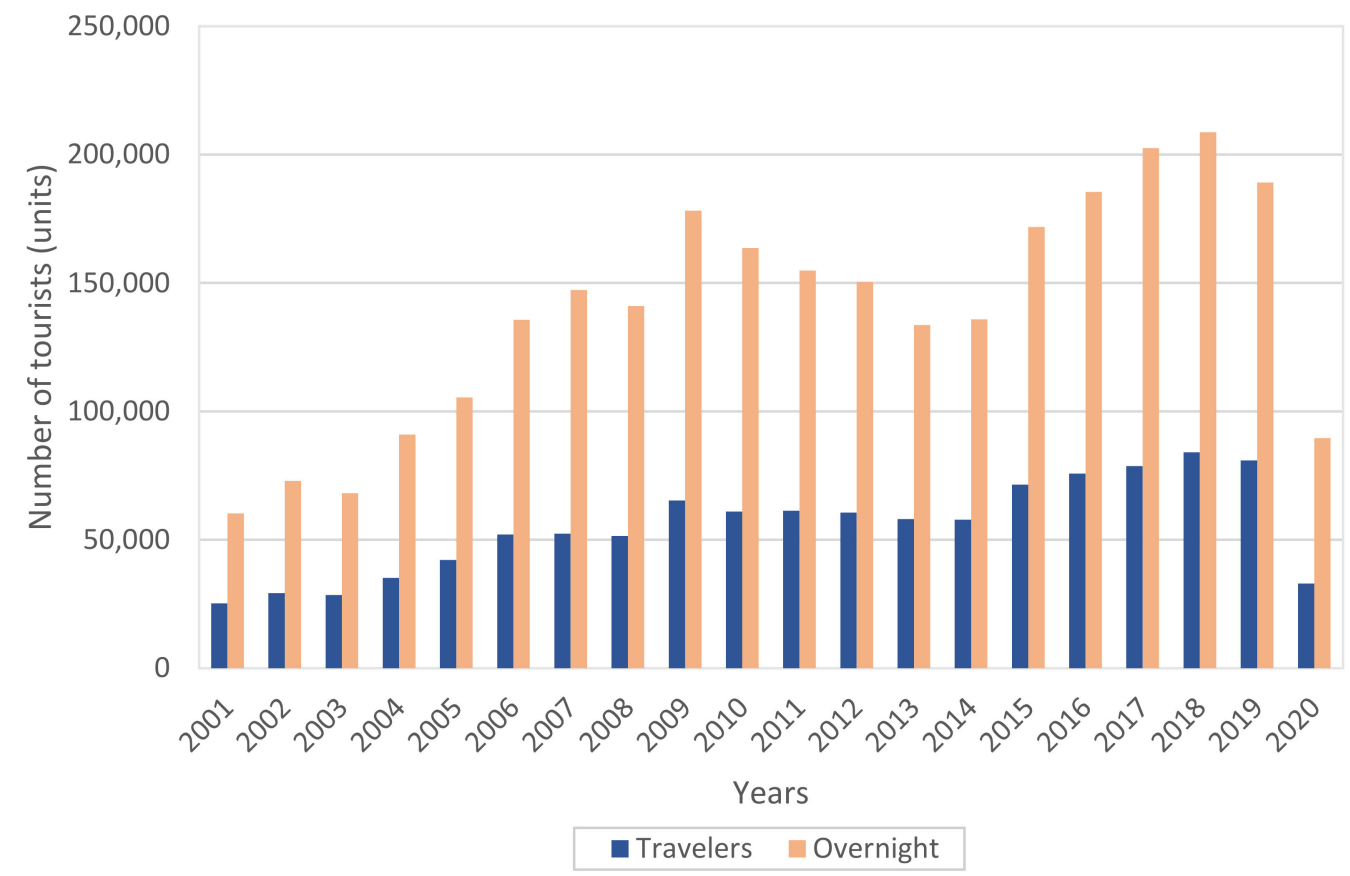

Figure 2. Number of travelers and overnights (vertical figures) in rural tourism in the province of Soria by years (horizontal figures).

Despite these encouraging figures, we must also consider a problem that may affect all aspects of tourism in Spain. As Moreno et al. [13] explain, the long-term competitiveness of the Spanish tourism sector requires innovation, but tourism companies do not consider this to be necessary. This may lead to a situation in which certain resort areas reach saturation levels.

Our research is based on the analysis of the behavior of tourists who have stayed in rural accommodations in Soria province. Of the variables that have been studied to understand the behavior of the possible rural tourist, two motivations stand out: a variable located at the origin of any purchase decision process, and the image of the tourist destination. We consider both the affective component-which originates in the feelings that the destination generates-and the cognitive component, which is generated from external, publicly accessible knowledge. The information obtained from a large sample collected in Soria province will be analyzed below, and then the principal results and conclusions will be presented.

\section{Conceptual Framework and Hypothesis}

\subsection{Research Framework}

Motivations can be described as the "driving force" of the entire process that leads a person (consumer) to make a purchase. For Santesmases [31], a reason is "the reason why a product is purchased". The consumer buys for the benefits provided by the acquisition and use of the product and, through these benefits, satisfies certain needs. Therefore, motivation is, in the words of this same author, "the general predisposition that directs behavior towards obtaining what is desired". Similarly, Kotler [32] defined motivation as 
"a need that presses enough to drive the person to act". Therefore, it is important to study and know the main motivations that move the consumer to carry out an activity.

Several authors who focused on tourism [33-40] also defined motivation in this area as the engine that impels or rejects the activity, this being the conditioning factor of the entire decision process. Others, such as Albayrak and Caber [41], highlighted post-trip motivation as a variable that strongly influences total satisfaction, and compared it to pre-trip motivation, which has little influence.

Among the pioneering studies of the importance of motivation in tourist activity, Dann [42] and Crompton [43] stand out. In the latter, the "push" motive and "pull" motive are brought up for the first time. This author presented a list of nine motives, which were later expanded by Crandall [44] to seventeen. After them, other authors have emphasized the importance of motivations in tourism: Lopes [45] and Pérez and García [46], explaining that motivations are the origin of the tourist's decision, in addition to the destination image, which is a basic element in the whole process; and Matute et al. [47] and Hsu [48], who, in his model of tourist behavior, concluded that it is directly related to motivation, as well as to the expectations generated before the trip.

Therefore, to promote an area as a tourist area, and especially if it has undergone a high degree of depopulation, it is necessary to carry out studies that focus on discovering the main motivations of tourists that can influence them to choose activities compatible with rural tourism.

The importance of the destination image in the entire tourist selection process has already been highlighted. In this respect, Önder and Marchiori [49], when considering that it is a relevant component of the tourist's choice of destination, use various sources to induce positive images in the tourist. For Marine and Ferrer [50], the destination image is crucial when planning a trip. Among the different definitions of the concept of destination image, the one offered by Baloglu and McCleary [51] stands out. For these authors, the image is the "mental representation of knowledge, feelings and global impressions that each individual has of an object or destination". In this definition, we observe that these authors divide the destination image into three different parts: the cognitive part, which is that which we obtain through knowledge; the affective part, which is that which we obtain through our feelings; and the global part of the image, which is the sum of both components. These authors, therefore, divided the image into two components: the cognitive and the affective, which together make up what is known as the global destination image. This global image, a key and highly personal variable, is a true filter of the entire process. Another very useful definition of destination image is given by López-Sanz et al. [52], where they indicated that the destination image is the overall mental impression each person has of a place or destination, as formed by knowledge, as well as by the feelings that the destination produces in them.

Similarly, other authors focused their studies on the formation of the affective and cognitive components of the image. Of these, we would draw attention to: Sanz [53], who defined the destination image as "the global perception of said destination, that is, the representation in the mind of the tourist who knows and feels about it"; Seongseop et al. [54], who analyzed the differences between the affective image, which is much more volatile, and the cognitive image, which lasts; Beerli et al. [55], who explained that the differentiation between these two components allows us to understand how tourists value places; and Machado et al. [56], for whom the image of the place, both affective and cognitive, tends to become stronger after the visit. For their part, Zhang et al. [57] also emphasized both components of the global destination image.

In another study, carried out by Echtner and Ritchie [58], they defined the principal variables to be used in measuring the destination image, using both structured and unstructured methods. This scheme was followed by numerous authors who aimed to measure the importance of the destination image in tourists, and to identify the main variables. Of these authors, we would highlight Choi et al. [59], Hui and Wan [60], Konecnik [61], Deslandes [62], and San Martín et al. [63]. 
At this point, it is necessary to emphasize that, of the information analyzed, the variable that has the most influence both on the formation of the global image and on the cognitive and affective image is, as explained in the study by Baloglu and McCleary [51], the tourist's motivations.

Other authors, such as Cardoso et al. [64], explained that the tourist destination, through its image, can be perceived by tourists in two ways: as a favorite destination, which is influenced by a retrospective thought of a positive experience in the place itself; or as a dream destination, based on the tourist's prospective memory. The favorite destination refers to a place that the tourist has already visited and considers the best destination for a particular type of trip, while the dream destination is a place that the tourist has never visited, but harbors desires to know in the future.

Another essential element in studying destination image is the contribution to the tourist's behavior made by the new, post-trip image. As the analysis by Sanz [53] shows, the initial destination image is what attracts a tourist to a location, but after the visit, this initial image is modified. If this change is positive, it enhances brand loyalty towards that place. Lima and Costa [65] also differentiated between the initial image (defined by these authors as imaginary), which is that generated by the tourist in his imagination from a set of information, and the final, post-trip image, which is the one generated after the visit and is used to communicate and inform about the tourist destination.

\subsection{Research Hypothesis}

As we have verified from our review of the literature, the tourist's motivations and pre-trip image of the destination are the elements that most strongly influence the formation of the final destination image or post-trip image. As several authors have explained, the destination image, which we refer to as the global destination image, is formed from the affective and cognitive components. Both components have a very significant influence on this formation process, although some authors, such as Baloglu and McCleary [51], have stated that the affective component of the image has a much greater influence than the cognitive component. Then again, for Lekovic et al. [66], it is the cognitive component of the image that has the most influence on the formation of the new image of the destination.

Currently, as García et al. [67], Campillo-Alhama and Martínez-Sala [68], and CuestaValiño et al. [69] explain, the use of ICT and particular social networks serve as tools when choosing our holiday destination, helping to form an image, initial or final, both through feelings (the affective component of the image) and knowledge (the cognitive component of the image). This again demonstrates the importance of both components in forming the final destination image, as well as in the choice of destination. As explained by Lee et al. [70], both the cognitive and affective components are important for the formation of the new image of the destination.

Given the foregoing, we proceed to define the following study hypotheses referring to both components of the image:

Hypothesis 1a. The affective component of the image has a positive influence on the formation of the new destination image.

Hypothesis 1b. The cognitive component of the image has a positive influence on the formation of the new destination image.

Regarding tourist motivations, several authors have discussed the different factors into which they can be divided [71-76]. However, within this division into the different motivational variables that influence the tourist, and, therefore, the formation of the initial and final destination images, as well as the choice of the trip, several authors consider that one specific motivation is far more influential than the others. Luo and Deng [77] focus on the importance of a love of nature as a motivation in this process, as do [73,74,78,79].

Other authors, notably Van der Merwe et al. [80], have focused on social motivations as the driving force behind the trip, and also consider that social motivations constitute 
the principal motivating factor that influences the formation of the destination image. Lee et al. [81] and Park et al. [82] also studied social motivations as the driving force behind the trip, and as influencing the formation of the destination image. Several authors focus on this component for their studies $[83,84]$, which indicates the importance of this variable in the formation of the new destination image.

Finally, regarding the most influential motivational factors, we also highlight the escape motivation, which is the translation of a need to flee from our routine and to find other areas or activities that allow us to escape for a few days. Michael et al. [85] spoke of the importance of escape motivation and focused on three escape factors: physical, interpersonal, and fun or entertainment. Carrascosa-López [78] also described this motivtional variable and its importance. It is, however, the work of Kaulbars [86] that considers that this type of motivation is most important, both in the choice of tourism and in the formation of the initial and final destination images.

We therefore proceed to define the following hypotheses, which focus on tourist motivations:

Hypothesis 2a. The motivational factor that references nature and culture has the most influence on the formation of the new destination image.

Hypothesis 2b. Social motivations have an important influence on the formation of the new destination image.

Hypothesis 2c. Escape motivations have an important influence on the formation of the new destination image.

We thus observe that both the motivations and the pre-trip destination image, with its two variables - cognitive and affective - very strongly influence the formation of the tourist's new, post-trip destination image. As explained in the work by López-Sanz et al. [87], as well as Gunn [88], Sanz [53], and Lima and Costa [65], the image of the destination-the initial, pre-trip image-is the variable that has the most influence on the formation of the new, post-trip destination image. We therefore present the last hypothesis of our study.

Hypothesis 3. The destination image is the variable that most influences the formation of the new destination image.

\section{Methods}

Survey Design

As previously indicated, the objective of this research is to analyze the behavior of tourists visiting rural areas. To this end, we must first verify the key roles that both motivations and the pre-trip image have in the tourist's choice process and, secondly, establish the relationships between motivations and the destination image in the formation of the new image.

For this research, data has been collected through a questionnaire. The fieldwork was carried out in the province of Soria in 2017; 1658 questionnaires were collected from tourists over 18 who stayed in a rural tourism establishment in the province.

Several multivariate techniques have been applied to the data collected, such as Principal Component Analysis (PCA). Later, a Multiple Classification Analysis (ACM) was run on the factors obtained. The statistical analysis of the data has been carried out using the DYANE program [89].

The questionnaire is composed of five main sections, as you can see in Table 1 . The first one is about the experience of the tourist in the destination area; the second part studies the tourist's pre-trip destination image; the third part is about the different factors that motivate the tourist to travel; the fourth studies tourist satisfaction; and the fifth focuses on the new post-trip destination image. All of the items were selected after an extensive bibliographic review, and a four-point Likert scale was used, where 4 is "a lot" and 1 is "nothing". 
Table 1. Scales and sources of adoption.

\begin{tabular}{ccc}
\hline Items & Number of Items & Source of Adoption \\
\hline Cognitive Image & 31 & {$[44]$} \\
\hline Affective Image & 4 & {$[37]$} \\
\hline Motivation & 24 & {$[29,30]$} \\
\hline New Image & 1 & {$[39]$} \\
\hline
\end{tabular}

To evaluate the scales and check that they had been constructed correctly, a pretest was performed on 50 tourists who had visited the area. The data was then collected personally in the Soria province, yielding a sample of 1658 valid and representative answers.

\section{Results}

Before considering the results obtained in the research, we need to list those motivational attributes, as well as the attributes of both the affective and cognitive images that we have used in the survey. Based on our review, Table 2 shows the list of motivations analyzed, as well as the attributes of the cognitive image and those used to measure the affective image.

Table 2. Motivations and image attributes.

\begin{tabular}{|c|c|}
\hline \multicolumn{2}{|c|}{ Motivational Items } \\
\hline Escape the routine & Do nothing \\
\hline Experience adventure and excitement & Do things you wouldn't normally do. \\
\hline Have fun, entertain yourself & Improve health \\
\hline Meditate on yourself & Be in contact with nature \\
\hline Relaxation & Practice sports activities \\
\hline Prestige & Visit the places where the family comes from \\
\hline Improved family relationships & Labor reasons \\
\hline Facilitate social relationships & Attending cultural or religious events \\
\hline Meet new people & Relive past times with the comforts of the present \\
\hline Experiencing new and different lifestyles & Get to know new places \\
\hline Go to places you have not known before & Training \\
\hline $\begin{array}{c}\text { Visit a place to talk about when you get } \\
\text { home }\end{array}$ & $\begin{array}{l}\text { Go to places with historical, cultural, and } \\
\text { patrimonial wealth }\end{array}$ \\
\hline \multicolumn{2}{|c|}{ Cognitive image items } \\
\hline National parks and wildlife activities & Hospitality of its people \\
\hline Museums and tourist places & Rest, relaxation, and tranquility \\
\hline Parties, fairs, and festivals & Environment not degraded, clean and careful \\
\hline Interesting historical or cultural attractions & Opportunity for adventures \\
\hline Nightlife & Opportunity to increase knowledge \\
\hline Possibility of purchases & Oriented to both adults and families \\
\hline Ease of obtaining tourist information & Fame and reputation \\
\hline Ease of playing sports & Customs worth knowing \\
\hline
\end{tabular}


Table 2. Cont.

\begin{tabular}{cc}
\hline Interesting rural life & Luxurious place and accommodations \\
\hline Quality in accommodation & Great variety of fauna \\
\hline Good quality/price ratio & Ease of parking in tourist areas \\
\hline Favorable climate & Great variety of flora \\
\hline Agglomeration & Rustic places and accommodations \\
\hline Hygiene and Cleanliness & Good road communication networks in the area \\
\hline Easy accessibility from other regions & Interesting cities \\
\hline Attractive gastronomy & \\
\hline Fun & Affective image items \\
\hline Relaxation & Joy \\
\hline
\end{tabular}

Given the high number of variables, a factor analysis was performed, using the Principal Component Analysis technique.

Principal Component Analysis (PCA) is a statistical analysis technique that attempts to identify the structure of a set of observed variables. It is used to study the interrelationships between the variables, and thus find a new, smaller set of variables, that expresses what they have in common [89].

Regarding tourist motivations, we obtained five factors that explain $54.49 \%$ of the variance. The retained factors, as well as the variables that are most closely associated with each of them, are the following (Table 3):

Table 3. Retained motivational factors and its loadings.

\begin{tabular}{|c|c|c|c|c|c|}
\hline Variables & Factor 1 Loading & Factor 2 Loading & Factor 3 Loading & Factor 4 Loading & Factor 5 Loading \\
\hline Experience adventure and excitement & 0.3982 & & & & \\
\hline Meditate on yourself & 0.7568 & & & & \\
\hline Go to places you have not known before & -0.7082 & & & & \\
\hline $\begin{array}{l}\text { Visit a place to talk about } \\
\text { when you get home }\end{array}$ & -0.6301 & & & & \\
\hline Be in contact with nature & 0.8257 & & & & \\
\hline Practice sports activities & 0.8680 & & & & \\
\hline Labor reasons & 0.6187 & & & & \\
\hline Attend cultural or religious events & 0.7237 & & & & \\
\hline $\begin{array}{l}\text { Relive past times with the comforts } \\
\text { of the present }\end{array}$ & 0.7509 & & & & \\
\hline $\begin{array}{l}\text { Go to places with historical, cultural, and } \\
\text { patrimonial wealth }\end{array}$ & -0.7172 & & & & \\
\hline Get to know new places & -0.8233 & & & & \\
\hline Have fun, entertain yourself & & 0.7565 & & & \\
\hline Improved family relationships & & 0.6585 & & & \\
\hline Facilitate social relationships & & 0.6821 & & & \\
\hline Meet new people & & 0.6030 & & & \\
\hline Do things you wouldn't normally do & & 0.6790 & & & \\
\hline $\begin{array}{l}\text { Visit the places where the } \\
\text { family comes from }\end{array}$ & & 0.6393 & & & \\
\hline Do nothing & & & 0.6537 & & \\
\hline
\end{tabular}


Table 3. Cont.

\begin{tabular}{|c|c|c|c|c|c|}
\hline Variables & Factor 1 Loading & Factor 2 Loading & Factor 3 Loading & Factor 4 Loading & Factor 5 Loading \\
\hline Improve health & & & 0.7544 & & \\
\hline Prestige & & & & 0.6798 & \\
\hline Experiencing new and different lifestyles & & & & 0.6076 & \\
\hline Escape the routine & & & & & 0.6221 \\
\hline Relaxation & & & & & 0.6106 \\
\hline Training & & & & & 0.5091 \\
\hline
\end{tabular}

Factor 1, which we have called the "Cultural vs. natural" motivational factor, explains $27.06 \%$ of the variance.

Factor 2 relates to "Social" motivations, and explains $12.67 \%$ of the variance.

Factor 3 is represented by motivations of a strictly "Personal" nature and explains $5.23 \%$ of the variance.

Factor 4 explains $4.79 \%$ of the variance and is related to the impression of feeling better (prestige), in a different way, which we call "Novelty".

Factor 5 explains $4.79 \%$ of the variance and represents motivations related to escaping from habitual activity, which we will refer to as "Escape".

Applying PCA to the variables of the tourist's cognitive image offers five factors that explain $46.39 \%$ of the variance. The factors retained, with the variables that present the strongest associations with each of them, are listed below (Table 4):

Table 4. Retained cognitive image factors and its loadings.

\begin{tabular}{|c|c|c|c|c|c|}
\hline Variables & Factor 1 Loading & Factor 2 Loading & Factor 3 Loading & Factor 4 Loading & Factor 5 Loading \\
\hline Ease of playing sports & 0.7882 & & & & \\
\hline Quality in accommodation & -0.6466 & & & & \\
\hline Favorable climate & 0.8992 & & & & \\
\hline Agglomeration & 0.9016 & & & & \\
\hline Easy accessibility from other regions & -0.5150 & & & & \\
\hline Opportunity for adventures & 0.5539 & & & & \\
\hline Oriented to both adults and families & 0.7237 & & & & \\
\hline Great variety of fauna & 0.5400 & & & & \\
\hline Ease of parking in tourist areas & 0.3967 & & & & \\
\hline Great variety of flora & 0.5681 & & & & \\
\hline Rustic places and accommodations & 0.5502 & & & & \\
\hline $\begin{array}{l}\text { Good road communication networks } \\
\text { in the area }\end{array}$ & 0.7515 & & & & \\
\hline Museums and tourist places & & 0.7502 & & & \\
\hline Interesting historical or cultural attractions & & 0.5850 & & & \\
\hline Ease of obtaining tourist information & & 0.4773 & & & \\
\hline Attractive gastronomy & & 0.6119 & & & \\
\hline Opportunity to increase knowledge & & 0.6287 & & & \\
\hline Customs worth knowing & & 0.5931 & & & \\
\hline Interesting cities & & 0.5784 & & & \\
\hline Parties, fairs, and festivals & & & 0.7156 & & \\
\hline Nightlife & & & 0.6590 & & \\
\hline Possibility of purchases & & & 0.5443 & & \\
\hline Fame and reputation & & & 0.6841 & & \\
\hline Luxurious place and accommodations & & & 0.5335 & & \\
\hline National parks and wildlife activities & & & & 0.7840 & \\
\hline
\end{tabular}


Table 4. Cont.

\begin{tabular}{|c|c|c|c|c|c|}
\hline Variables & Factor 1 Loading & Factor 2 Loading & Factor 3 Loading & Factor 4 Loading & Factor 5 Loading \\
\hline Interesting rural life & & & & 0.5257 & \\
\hline Rest, relaxation, and tranquility & & & & 0.6525 & \\
\hline $\begin{array}{l}\text { Environment not degraded, } \\
\text { clean and careful }\end{array}$ & & & & 0.5197 & \\
\hline Good quality/price ratio & & & & & 0.5932 \\
\hline Hygiene and Cleanliness & & & & & 0.5630 \\
\hline Hospitality of its people & & & & & 0.6024 \\
\hline
\end{tabular}

Factor 1, which provides the most significant explanation of the variance $(20.23 \%)$, offers high correlations with variables related to tourist variety versus situational elements.

Factor 2, which provides $8.84 \%$ of the explanation, is related to cultural variables, or expansion of knowledge.

Factor 3, which explains $7.66 \%$ of the variance, is associated with elements of fun or entertainment and social life.

Factor 4 , with $5.89 \%$ of the variance, is associated with rest or relaxation and the environment.

Factor 5, which explains $3.77 \%$ of the variance, is associated with elements that make an accommodation attractive.

For the tourist's affective image, when PCA was applied to its four variables, we obtained two factors that explain $65.78 \%$ of the variance (Table 5):

Table 5. Retained cognitive image factors and its loadings.

\begin{tabular}{ccc}
\hline Variables & Factor 1 Loading & Factor 2 Loading \\
\hline Fun & 0.8675 & \\
\hline Joy & 0.7560 & \\
\hline Relaxation & & 0.7274 \\
\hline Pleasant & & 0.7467 \\
\hline
\end{tabular}

Factor 1, which explains $36.20 \%$ of the variance and is mainly associated with variables typical of the external affective image.

Factor 2, with $29.58 \%$ of the variance, is associated with variables of the internal affective image.

By applying PCA, a new and smaller set of variables (factors) have been obtained, which express what is common to the original variables that were taken as a starting point in the investigation of motivations and the cognitive and affective images. In addition, the reduction in the set of variables - both for the motivations analyzed and the variables that explain the pre-trip destination image-facilitates the use of other techniques that explain the relationship between different variables, such as Multiple Classification Analysis.

According to Santesmases (2009) [89], Multiple Classification Analysis (MCA) offers notable advantages both in data management and in the interpretation of results. The objective of this technique is to analyze the relationship between a dependent variable or criterion and a different explanatory or predictor variables. The first must be measured on either a metric or a dichotomous scale, while the explanatory or independent variables must be measured using non-metric or categorical scales.

In our case, we have chosen the new destination image as the dependent variable or criterion that we want to explain, and motivation and pre-trip image (cognitive and affective) as predictive or explanatory variables. This analysis allows us to understand which variables, in contributing to motivation and previous tourist image, have the greatest influence in generating the new destination image after the trip. As explanatory variables, 
we will use the factors that we have obtained in the factor analysis, which represent both the motivations of the rural tourist and the tourist destination image.

In the new destination image variable, the sample analyzed had previously been asked if, once they had stayed in a rural tourist accommodation in the province of Soria, their new image had changed with respect to the pre-trip image. The results were very positive. For $73.58 \%$ of those surveyed, the post-trip destination image was better or much better than the pre-trip image, and only $0.97 \%$ indicated that their image had become worse.

Using this information, we look for the relationship by applying the MCA technique to the following variables: new image (criterion variable to be explained); and motivations and image (explanatory variables).

Table 6 summarizes the results obtained from each of the analyses.

Table 6. Explanation of variance motivational and previous image factors on the new destination image.

\begin{tabular}{cc}
\hline Motivational explanatory variables (factors) & Variance Expl. \\
\hline Cultural and natural motivations & $21.73 \%$ \\
\hline Social motivations & $16.91 \%$ \\
\hline Personal motivations & $1.57 \%$ \\
\hline Novelty motivations & $0.98 \%$ \\
\hline Escape motivations & $7.35 \%$ \\
\hline Cognitive image “Tourist variety versus situational elements” & Variance Expl. \\
\hline Cognitive image “Interesting culture" & $22.25 \%$ \\
\hline Cognitive image “Fun" & $6.10 \%$ \\
\hline Cognitive image “Rest and interesting environment & $9.25 \%$ \\
\hline Cognitive image “Attractive accommodations” & $7.52 \%$ \\
\hline External affective image & $0.53 \%$ \\
\hline Internal affective image & $11.28 \%$ \\
\hline
\end{tabular}

Table 6 shows that the motivational variables grouped in factor 1 -cultural and natural - are the most explanatory, followed by social and escape variables. Personal motivations, however, have very little influence, and the influence of novelty is negligible. The analysis of the influence of the pre-trip images (cognitive and affective) on the formation of the post-trip image of the tourist destination shows that, of the variables based on the prior images (cognitive and affective), the most explanatory is the cognitive image, referred to as touristic variety combined with accessibility and facilities, i.e., variety of tourist and natural attractions combined with good facilities and transport links. Next in importance, although less influential, is the external affective image. Except for the cognitive variable of attractive accommodation, whose influence is imperceptible, the other variables have an influence, especially those related to fun. Rest/relaxation, interesting environment, and culture are significant, although to a lesser degree.

As a result of these analyses, we can state that, firstly, tourists' new, i.e., post-trip image is, for the most part, better or much better than the initial image:

- It is the cultural and nature-related motivations and, to a lesser extent, the social ones, that have contributed the most to this new destination image.

- Concerning the pre-trip image, the cognitive image referred to as touristic variety combined with accessibility and facilities has most strongly influenced this new and improved destination image. On the other hand, the external affective image, which is much more rooted in the tourists' feelings, has also had an important influence on this new image, although to a lesser extent than the cognitive image factor mentioned above.

Table 7 summarizes the hypotheses that we have proposed in this study. 
Table 7. Summary of hypothesis verification.

\begin{tabular}{ccc}
\hline Hypothesis & \multicolumn{1}{c}{ Content } & Verification \\
\hline $\mathrm{H} 1 \mathrm{a}$ & $\begin{array}{c}\text { Affective component of image has a positive } \\
\text { influence in the new destination } \\
\text { image formation }\end{array}$ & Supported \\
$\mathrm{H} 1 \mathrm{~b}$ & $\begin{array}{c}\text { Cognitive component of image has a positive } \\
\text { influence in the new destination } \\
\text { image formation }\end{array}$ & Supported \\
$\mathrm{H} 2 \mathrm{a}$ & $\begin{array}{c}\text { The motivational factor referring to nature } \\
\text { and culture is the most influential on the } \\
\text { formation of the new destination image }\end{array}$ & Supported \\
$\mathrm{H} 2 \mathrm{~b}$ & $\begin{array}{c}\text { Social motivations have an important } \\
\text { influence on the formation of the new } \\
\text { destination image }\end{array}$ & Supported \\
$\mathrm{H} 2 \mathrm{c}$ & $\begin{array}{c}\text { Escape motivations have an important } \\
\text { influence on the formation of the new } \\
\text { destination image }\end{array}$ & Supported \\
\hline $\mathrm{H} 3$ & $\begin{array}{c}\text { The destination image is the variable that } \\
\text { most influences the formation of the } \\
\text { destination image }\end{array}$ & Supported \\
\hline
\end{tabular}

\section{Discussions and Conclusions}

\subsection{Theoretical Implications}

Based on a wide-ranging bibliographic review, and after analyzing the results of our extensive empirical research, the tourist's motivations and destination image have been shown to be the two aspects that are fundamental to understanding the behavior of rural tourists $[51,53]$. This study will assist those people and agencies that wish to offer rural tourism activities that will support further development in many of Spain's unpopulated areas. As we have seen, these areas have great potential for new and sustainable development, thanks to the rise of rural tourism and other types of tourism that are more environmentally friendly and respect the activities of the local population.

The motivations behind tourists' decisions to go on holiday and choose one destination over another are numerous. After completing the literature review, a list of the twenty-four most important motivations was drawn up.

Destination image has also been extensively analyzed in the literature. It is a key factor in understanding why tourists choose one place over another for a rural holiday. After reviewing the existing literature, the image of the tourist destination was synthesized into thirty-one cognitive attributes and four affective attributes [51].

Using the definitions of variables, and after data collection, we proceeded to analyze these variables and the data. We used several techniques that allowed us to observe not only the individual variable but—and more importantly—each variable in relation to other variables. The aim was to establish how much influence the tourist's motivations and the pre-trip destination image have on the new destination image. The techniques used, in addition to basic statistics, were Principal Component Analysis (PCA) and Multiple Classification Analysis (ACM)

Principal Component Analysis (PCA) allowed us to obtain a series of factors that group the variables by concentrating the underlying information. The grouping of variables into factors has also facilitated the subsequent analysis of the data. For tourist motivation, we obtained five factors that explained $54.49 \%$ of the variance. We named these motivational factors as follows: cultural vs. natural; social; personal; novelty; and escape. For the destination image, we also obtained five cognitive factors, which explained $46.39 \%$ of the variance (touristic variety combined with accessibility and facilities; interesting culture; fun; interesting environment and rest/relaxation; and attractive accommodation options) 
and two affective factors, with an explanation of variance of $65.78 \%$ (external affective image and internal affective image).

Using Multiple Classification Analysis (MCA), the influence of motivations and the destination image in the formation of the new destination image was analyzed. We found that the cognitive image of touristic variety combined with accessibility and facilities had the greatest influence on forming this image, with an explanation of variance of $22.25 \%$. Next, but very close, were the influence of cultural and natural motivations, with an explanation of variance of $21.73 \%$, and social motivations with an explanation of variance of $16.91 \%$. Less important was the external affective image, which provided $11.28 \%$ of the explanation.

\subsection{Managerial Implications}

These results show that, if we want to promote tourist destinations and accommodation as a wealth creation activity, clarifying key tourist motivations is a priority. The influence of these motivations on modifying the pre-trip image of a destination to create the post-trip image has been proven in the case of Soria province. The prior image of the destination is also an essential factor, since this initial image, especially the cognitive image, has a strong influence on the formation of the new destination image. The affective image must also be taken into consideration. This study also proved that a tourist's post-trip image, in the case of Soria province, is much better than the one with which they began the trip.

In turn, once the motivations and variables of the most influential prior image are known, actions must first be taken to satisfy them and thus positively influence the post-trip image. It is essential, through communication, to inform the general public of all of the potential the province offers.

Traditional marketing actions are not sufficient to achieve this goal. Spain is a country where innovation is not considered to be necessary, especially by companies in the hospitality industry, but this must change. Traditional marketing activities must be maintained, but new types of actions are essential to satisfy the motivations detected in this study and promote attractive images prior to the visit. Rural and mountainous environments can offer aspects of culture and landscape that allow a greater degree of participation than more traditional destinations. In participatory tourism, visitors can integrate and participate in the activities, tasks, and customs of the place, which in turn ensures that the traditions of the area are not lost. The tourist wants to escape, discover, enjoy, and connect with the local people. Activities related to agrotourism, wine tourism, and adventure are very useful for attracting tourists' attention and making a rural tourism area more attractive. In addition, they allow tourists to get involved, so that, in addition to the traditional sight-seeing and relaxation, there are activities in which tourists can be involved and take an active role. An area's existing resources must be analyzed and incentivized to make them attractive to tourists. These include popular festivals, but also activities in which tourists can participate in recreating the lives of previous generations, and the cultural wealth of the area.

In short, by developing, enhancing, and communicating the innumerable natural and cultural resources of the region, and seeking out those differential elements that can provide an unforgettable tourist experience, a viable activity can be created for the future of these unpopulated areas.

\subsection{Limitations and Future Research}

The main limitation of this study is that it focuses on only one of Spain's provinces. It is, however, the one with the fewest inhabitants. It would therefore be interesting to make a similar study, using the same statistical techniques, of other areas with similar characteristics.

Another future line of research would be to apply other appropriate statistical techniques to this study to verify the results we have obtained. The Structural Equation Analysis technique could be used to confirm the relationships we have found. 


\subsection{Conclusions}

In summary, we have shown that, after visiting a tourist destination, especially one with a high level of depopulation, the final destination image depends on several variables. The pre-trip destination image has the greatest influence on this post-trip image [90], with the cognitive component of the image having the greatest effect, contrary to the findings of Baloglu and McCleary [51]. It has also been proven that the tourist's motivations have an important influence on the new, post-trip tourist destination image, with natural and cultural motivations having the greatest influence. It has thus been demonstrated that a rural area must not only be associated with a good image, it must also be adequately promoted so that future tourists are aware of this good image [52], as it substantially influences the final destination image. The importance of how the characteristics of these territories is publicized has been demonstrated. The study also shows the importance of motivation based on a love of natural spaces and the culture of the region, so these elements should be emphasized when promoting a rural tourism area.

Author Contributions: Conceptualization, J.M.L.-S., A.P.-L., P.C.-V., and P.G.-R.; methodology, J.M.L.S., A.P.-L., P.C.-V., and P.G.-R.; software, J.M.L.-S., A.P.-L., P.C.-V., and P.G.-R.; validation, J.M.L.-S., A.P.-L., P.C.-V., and P.G.-R.; formal analysis, J.M.L.-S., A.P.-L., P.C.-V., and P.G.-R.; investigation, J.M.L.S., A.P.-L., P.C.-V., and P.G.-R.; resources, J.M.L.-S., A.P.-L., P.C.-V., and P.G.-R.; writing-original draft preparation, J.M.L.-S., A.P.-L., P.C.-V., and P.G.-R.; writing-review and editing, J.M.L.-S., A.P.-L., P.C.-V., and P.G.-R.; visualization, J.M.L.-S., A.P.-L., P.C.-V., and P.G.-R.; supervision, J.M.L.-S., A.P.-L., P.C.-V., and P.G.-R. All authors have read and agreed to the published version of the manuscript.

Funding: This research received no external funding.

Data Availability Statement: Not applicable.

Conflicts of Interest: The authors declare no conflict of interest.

\section{References}

1. Jiménez, M.; Peña, A.R.; Ruiz, J. La demanda turística internacional: Recuperación de la crisis y turismo de lujo, una primera aproximación al caso español. J. Reg. Res. Investig. Reg. 2017, 38, 47-66.

2. García, B.; Martínez, E. Estrategias de comunicación del turismo rural. In Proceedings of the En I Congreso Internacional Patrimonio, Desarrollo Rural y Turismo en el Siglo XXI, Osuna, Spain, December 2004.

3. Plaza, J.I. El turismo rural en territorios periféricos (el ejemplo de algunas comarcas del oeste castellano-leonés). Investig. Geogr. 2001, 27, 83-106. [CrossRef]

4. López, L.M.; López, J.M. Efecto desestacionalizador del turismo rural en las regiones españolas. Bol. Econ. ICE Inf. Comer. Esp. 2005, 2860, 18.

5. Ejarque, J. Marketing y Gestión de Destinos Turísticos. Nuevos Modelos y Estrategias 2.0; Piramide: Madrid, Spain, 2016.

6. Cánoves, G.; Herrera, L.; Villarino, M. Turismo rural en España: Paisajes y usuarios, nuevos usos y nuevas visiones. Cuad. Tur. 2005, 15, 63-76.

7. Aparicio, A.E. El turismo rural: Una de las alternativas al desarrollo rural en la Serranía de Cuenca. Cuad. Tur. 2004, 13, 73-89.

8. Porcal, M.C. Propuestas de actuación para el desarrollo turístico sostenible de una comarca rural de media montaña. Investig. Geogr. 2003, 32, 65-90. [CrossRef]

9. Ascanio, A. Turismo y desarrollo de la comunidad: Un primer paso para rescatar la identidad cultural. PASOS Rev. Tur. Patrim. Cult. 2004, 2, 155-161. [CrossRef]

10. Tubadji, A.; Nijkamp, P. Revisiting the Balassa-Samuelson effect: International tourism and cultural proximity. Tour. Econ. 2018, 24, 915-944. [CrossRef]

11. Vázquez, G.M.; Morales, E.J.; Pérez, L.M. Análisis del turismo gastronómico en la provincia de Córdoba. Tour. Manag. Stud. 2012, $8,78-87$.

12. Hernández, J.M.; Di Clemente, E.; López, T. El turismo gastronómico como experiencia cultural. El caso práctico de la ciudad de Cáceres (España). Bol. Asoc. Geógr. Esp. 2015, 68, 407-427. [CrossRef]

13. Moreno, L.; Ramón, A.; Such, M.J. The challenge of long-term tourism competitiveness in the age of innovation: Spain as a case of study. J. Reg. Res. Investig. Reg. 2018, 42, 13-34.

14. Gretzel, U. From smart destinations to smart tourism regions. J. Reg. Res. Investig. Reg. 2018, 42, 171-184.

15. Gauna, C. Poblamiento, desarrollo, conservación y conflicto en la costa de Jalisco: Una revisión histórica. PASOS Rev. Tur. Patrim. Cult. 2019, 17, 193-207. [CrossRef]

16. Delgado, C. Depopulation Processes in European Rural Areas: A case Study of Cantabria (Spain). Eur. Countrys. 2019, 11, 341-369. [CrossRef] 
17. Fihel, A.; Okólski, M. Population decline in the post-communist countries of the European Union. Popul. Soc. 2019, 567, 1-4.

18. Rychtaříková, J. Demographic Transition or Demographic Shock in Recent Population Development in the Czech Republic? Acta Univ. Carol. Geogr. 2000, 35, 89-102.

19. Pinilla, V.; Ayuda, M.-I.; Sáez, L.-A. Rural depopulation and the migration turnaround in Mediterranean Western Europe: A case study of Aragon. J. Rural. Community Dev. 2008, 3, 1-22.

20. Johnson, K.M.; Lichter, D.T. Rural Depopulation: Growth and Decline Processes over the Past Century. Rural. Sociol. 2019, 84, 3-27. [CrossRef]

21. Ballas, D.; Kalogeresis, T.; Labrianidis, L. A comparative study of typologies for rural areas in Europa. In Proceedings of the 43rd European Congress of the Regional Science Associatio, Jyväskylä, Finland, 27-30 August 2003.

22. Nieto, A.; Cárdenas, G.; Engelmo, A. Spatial Analysis of the Rural-Urban structure of the Spanish Municipalities. Int. J. Geo-Inf. 2020, 9, 213. [CrossRef]

23. Desbordes, F.; Laborie, J.P. L'évolution récente de la population dans les Pyrénées françaises. Rev. Géogr. Pyren. Sud-Ouest 1991, 62, 7-18. [CrossRef] [PubMed]

24. Mathieu, J. Storia delle Alpi 1500-1900. Ambiente, Sviluppo e Società; Casagrande: Bellinzona, Italy, 2000.

25. Wrigley, E.A. Country and town: The primary, secondary, and tertiary peopling of England in the early modern period. In The Peopling of Britain; Slack, P., Ed.; Oxford University Press: Oxford, UK, 2001.

26. Short, B. Rural demography, 1850-1914. In The Agrarian History of England and Wales VII: 1850-1914; Collins, E.J.T., Ed.; Cambridge University Press: New York, NY, USA, 2000; pp. 1.232-1.296.

27. Fath, J.; Hunya, G. Cross-Border economic co-operation on present and future EU borders, a summary of findings. Enlarg. Res. Bull. 2001, 2, 1-10.

28. Recaño, J. La sostenibilidad demográfica de la España vacía. Perspect. Demogr. 2017, 7, 1-4.

29. Instituto Nacional de Estadística. Available online: https://www.ine.es/dyngs/INEbase/es/operacion.htm?c=Estadistica_C\& cid $=1254736177012 \&$ menu=ultiDatos\&idp=1254734710990 (accessed on 15 July 2021).

30. Antequera, E. Un análisis breve de las características de la despoblación en la provincia de Soria. Cuad. Ord. Territ. 2018, 6, 57-62.

31. Santesmases, M. Marketing: Conceptos y Estrategias, 6th ed.; Pirámide: Madrid, Spain, 2012.

32. Kotler, P. Dirección de Marketing, 15th ed.; Pearson: Mexico City, Mexico, 2016.

33. Solomon, M. Comportamiento del Consumidor, 7th ed.; Prentice Hall: Madrid, Spain, 2008.

34. Martín, M.; Manera, J.; Pérez, E. Marketing Fundamental; McGraw Hill: Madrid, Spain, 1997.

35. Schiffman, L.G.; Kanuk, L. El Comportamiento del Consumidor, 3rd ed.; Prentice Hall: Madrid, Spain, 2005.

36. Martín, E. Marketing; Ariel Economía: Barcelona, Spain, 1993.

37. Antonides, G.; Van Raaij, W.F. Consumer Behaviour: An European Perspective; John Wile \& Sons: London, UK, 1998.

38. Hoffman, K.D.; Czinkota, M.R.; Dickson, P.R.; Dunne, P.; Griffin, A.; Hutt, M.D.; Krishnan, B.C.; Lusch, R.F.; Ronkainen, I.A.; Rosenbloom, B.; et al. Principios de Marketing y sus Mejores Prácticas, 3rd ed.; Thomson: Mexico City, Mexico, 2007.

39. Rivera, J.; De Garcillán, M. Dirección de Marketing. Fundamentos y Aplicaciones, 2nd ed.; ESIC: Madrid, Spain, 2009.

40. Mediano, L. La Gestión de Marketing en el Turismo Rural; Pearson Prentice Hall: Madrid, Spain, 2004.

41. Albayrak, T.; Caber, M. Examining the relationship between tourist motivation and satisfaction by two competing methods. Tour. Manag. 2018, 69, 201-213. [CrossRef]

42. Dann, G. Anomie, ego-enhancement and tourism. Ann. Tour. Res. 1977, 4, 184-194. [CrossRef]

43. Crompton, J.L. An assessment of the image of Mexico as a vacation destination and the influence of geographical location upon that image. J. Travel Res. 1979, 17, 18-23. [CrossRef]

44. Crandall, R. Motivations for leisure. J. Leis. Res. 1980, 12, 45-53. [CrossRef]

45. Lopes, E. La motivación turística: El caso de la región de las aguas termales de Goias, Brasil. Bol. Asoc. Geógr. Esp. 2006, 42, 303-314.

46. Pérez, J.A.; García, Y. Turismo rural en Extremadura. El caso del "Turismo paisano". Rev. Esp. Estud. Agrosoc. Pesq. 2005, 206, 303-314.

47. Matute, M.; Aguilar, S.; Asanza, P.X. Aspectos Sociopsicológicos del Turismo. Available online: www.eumed.net/libros/2006c/20 9 (accessed on 1 June 2006).

48. Hsu, C.; Cai, L.; Li, M. Expectation, motivation and attitude: A tourist behavioural model. J. Travel Res. 2010, 49, 282-296. [CrossRef]

49. Önder, I.; Marchiori, E. A comparison of pre-visit beliefs and projected visual images of destinations. Tour. Manag. Perspect. 2017, 21, 42-53. [CrossRef]

50. Marine, E.; Ferrer, B. Measuring the gap between projected and perceived destination images of Catalonia using compositional analysis. Tour. Manag. 2018, 68, 236-249. [CrossRef]

51. Baloglu, S.; McCleary, K.W. A model of destination image formation. Ann. Tour. Res. 1999, 26, 868-897. [CrossRef]

52. López-Sanz, J.M.; Penelas-Leguía, A.; Gutiérrez-Rodríguez, P.; Cuesta-Valiño, P. Sustainable development and consumer behavior in rural tourism. The importance of image and Loyalty for host communities. Sustainability 2021, 13, 4763. [CrossRef]

53. Sanz, S. Imagen global e intenciones futuras de comportamiento del turista de segunda residencia. Rev. Eur. Dir. Econ. Empresa 2008, 17, 95-114.

54. Seongseop, S.; McKercher, B.; Lee, H. Tracking tourism destination image perception. Ann. Tour. Res. 2009, 36, 715-718. 
55. Beerli, A.; Martín, J.; Moreno, S. Los Agentes que Conforman la Imagen de los Destinos Turísticos. Available online: http: //www.esade.edu/cedit2003/pdfs/morenosergio.pdf (accessed on 14 February 2003).

56. Machado, L.P.; Santos, C.; Sarmento, M. Madeira Island. Destination image and tourist royalty. Eur. J. Tour. Res. 2009, 2, 70-90.

57. Zhang, M.; Zjang, G.; Gursoy, D.; Fu, X. Message Framing and regulatory focus effects on destination image formation. Tour. Manag. 2018, 69, 397-407. [CrossRef]

58. Echtner, C.; Ritchie, J.R. The measurement of destination image: An empirical assessment. J. Travel Res. 1993, 31, 3-13. [CrossRef]

59. Choi, W.; Chan, A.; Wu, J. A qualitative and quantitative assessment of Hong Kong's image as a tourist destination. Tour. Manag. 1999, 45, 361-365. [CrossRef]

60. Hui, T.K.; Wan, T. Singapore's image as a tourist destination. Int. J. Tour. Res. 2003, 5, 305-313. [CrossRef]

61. Konecnik, M. Evaluating Slovenia's image as a tourism destination: A self-analysis process towards building a destination brand. J. Brand Manag. 2004, 11, 307-316. [CrossRef]

62. Deslandes, D. Assessing the image of St. Lucia: Does the type of visitor matter? J. East. Caribb. Stud. 2006, 31, 53-84.

63. San Martín, H.; Rodríguez del Bosque, I.; Vázquez, R. Análisis de la imagen en turismo mediante técnicas estructuradas y no estructuradas: Implicaciones competitivas para los destinos turísticos. Rev. Astur. Econ. RAE 2006, 35, 69-91.

64. Cardoso, L.; Dias, F.; De Araujo, A.F.; Andrés, M.I. A destination imagery processing model: Structural differences between dream and favourite destinations. Ann. Tour. Res. 2019, 74, 81-94. [CrossRef]

65. Lima, M.; Costa, A.R. A imagem do destino turístico como ferramenta de diferenciacao e promocao do turismo: Caso de Barra Grande/PI-Brasil. PASOS Rev. Tur. Patrim. Cult. 2016, 14, 417-431.

66. Lekovic, K.; Tomic, S.; Maric, D.; Curcic, N.V. Cognitive components of the image of a rural tourism destination as a sustainable development potential. Sustainability 2020, 12, 9413. [CrossRef]

67. García, B.; Salvaj, E.; Cuesta-Valiño, P. A sustainable management model for cultural creative tourism ecosystems. Sustainability 2020, 12, 9554. [CrossRef]

68. Campillo-Alama, C.; Martínez-Sala, A.M. La estrategia de Marketing turístico de los Sitios Patrimonio Mundial a través de los eventos 2.0. PASOS Rev. Tur. Patrim. Cult. 2019, 17, 425-452. [CrossRef]

69. Cuesta-Valiño, P.; Bolifa, F.; Nuñez, E. Sustainable, Smart and Muslim-Friendly tourist destinations. Sustainability 2020, 12, 1778. [CrossRef]

70. Lee, S.; Scott, D.; Kim, H. Celebrity fan involvement and destination perception. Ann. Tour. Res. 2008, 35, 809-832. [CrossRef]

71. Buffa, F. Young tourists and sustainability. Profiles, attitudes and implication for destination strategies. Sustainability 2015, 7 , 14042-14062. [CrossRef]

72. Han, H.; Kim, W.; Kiatkawsin, K. Emerging youth tourism: Fostering young travellers' conservation intentions. J. Travel Tour. Mark. 2017, 34, 905-918. [CrossRef]

73. Gnoth, J.; Zins, A.H. Cultural dimensions and the international tourist role scale: Validation in asian destinations? Asia Pac. J. Tour. Res. 2010, 15, 111-127. [CrossRef]

74. Kim, S.S.; Prideaux, B. Marketing implications arising from a comparative study of international pleasure tourist motivations and other travel-related characteristics of visitors to Korea. Tour. Manag. 2005, 26, 347-357. [CrossRef]

75. Penelas-Leguía, A.; López-Sanz, J.M.; Cuesta-Valiño, P. Las motivaciones: Elemento de estudio esencial para un desarrollo turístico creativo en zonas despobladas. In Happiness Management and Creativity in the XXI Century; Ravina, R., Tobar, L.B., Nuñez, E., Eds.; Comares: Madrid, Spain, 2019; pp. 83-102.

76. Moreno, S.; Beerli, A.; De León, J. Entender la imagen de un destino turístico: Factores que la integran y la influencia de las motivaciones. Criterio Libre 2012, 10, 115-142.

77. Luo, Y.; Deng, J. The new environmental paradigm and nature-based tourism motivation. J. Travel Res. 2007, 46, 392-402. [CrossRef]

78. Carrascosa-López, C.; Carvache-Franco, M.; Mondéjar-Jiménez, J.; Carvache-Franco, W. Understanding motivations and segmentation in ecotourism destinations. Application to Natural Park in Spanish Mediterranean Area. Sustainability 2021, 13, 4802. [CrossRef]

79. Qiu, M.; Sha, J.; Scott, N. Restoration of visitors through Nature-based tourism: A systematic review, conceptual framework, and future research directions. Int. J. Environ. Res. Public Health 2021, 18, 2299. [CrossRef]

80. Van der Merwe, P.; Slabbert, E.; Saayman, M. Travel motivations of tourists to selected marine destinations. Int. J. Tour. Res. 2011, 13, 457-467. [CrossRef]

81. Lee, C.K.; Lee, Y.-K.; Wicks, B.E. Segmentation of festival motivation by nationality and satisfaction. Tour. Manag. 2004, 25, 61-70. [CrossRef]

82. Park, K.-S.; Reisinger, Y.; Kang, H.-J. Visitors' motivation for attending the South Beach wine and food festival, Miami Beach, Florida. J. Travel Tour. Mark. 2008, 25, 161-181. [CrossRef]

83. Yousaf, A.; Amin, I.; Santos, J.A. Tourists' Motivations to travel: A theorical perspective on the existing literature. Tour. Hosp. Manag. 2018, 24, 197-211. [CrossRef]

84. Vuuren, C.V.; Slabbert, E. Travel motivations and behaviour of tourists to a South African resort. Tour. Manag. Stud. 2011, 1, 295-304.

85. Michael, N.; Wien, C.; Reisinger, Y. Push and pull escape motivations of Emirati nationalto Australia. Int. J. Cult. Tour. Hosp. Res. 2017, 11, 274-296. [CrossRef] 
86. Kaulbars, J. Escape-The Real Motivation for Leisure Travel; GRIN Verlag: Munich, Germany, 2009; Available online: https: / / www.grin.com/document/231143 (accessed on 10 June 2020).

87. López-Sanz, J.M.; Penelas-Leguía, A.; Gutiérrez-Rodríguez, P.; Cuesta-Valiño, P. Rural tourism and the Sustainable Development Goals. A study of the variables that most influence the behavior of the tourist. Front. Psychol. 2021, 12, 722973. [CrossRef] [PubMed]

88. Gunn, C. Vacationscape: Designing Tourist Regions, 2nd ed.; Van Nostrand Reinhold: New York, NY, USA, 1993.

89. Santesmases, M. DYANE Versión 4. Diseño y Análisis de Encuestas en Investigación Social y de Mercados; Pirámide: Madrid, Spain, 2009.

90. López-Sanz, J.M.; Penelas-Leguía, A.; Cuesta-Valiño, P. Application of the multiple classification analysis for the study of the relationships between destination image, satisfaction and loyalty in rural tourism. J. Tour. Herit. Res. 2021, 4, $247-260$. 